\title{
A BREVE CARTA DE SARTRE SOBRE A NÃO ACEITAÇÃO DO PRÊMIO NOBEL DE LITERATURA
}

Nesta curta carta, encaminhada ao secretário da Academia Nobel, Sartre, após ficar sabendo de sua nomeação entre os finalistas Nobel de 1964 e, certamente ser o laureado, enviou esta mensagem antes mesmo da sua indicação/escolha, que ocorrera em 22 de outubro de 1964.

Carta de Jean-Paul Sartre, datada de 14 de outubro, endereçada ao Sr. Nils Stahl, a Fundação Nobel em Estocolmo, Suécia.

Jean-Paul Sartre

Boulevard Raspail, 222.

Paris.

14 de outubro de 1964.

Senhor secretário,

Após certas informações da qual tomei conhecimento hoje, eu teria, este ano, algumas chances de obter o Prêmio Nobel. Embora seja presunçoso em decidir por um voto, antes mesmo que ele ocorra, tomo neste instante, a liberdade de vos escrever para dissipar ou evitar um mal-entendido. Eu primeiramente o asseguro, Senhor Secretário, de minha profunda estima pela Academia Sueca e pelo prêmio com que esta honrou tantos escritores. Contudo, por razões que me são pessoais e por outras, mais objetivas, cujas mesmas não há por desenvolvê-las aqui, desejo [ne pas] não figurar na lista dos possíveis laureados e não posso nem quero - nem em 1964 nem mais tarde [nem depois] - aceitar esta distinção honorífica.

Eu vos peço Senhor Secretário, por aceitar minhas desculpas e em acreditar na minha mais elevada consideração ${ }^{1}$.

Assinado,

Jean-Paul Sartre.

\footnotetext{
${ }^{1}$ Traduzido da carta manuscrita e da transcrição francesa. Publicado por Vanessa Rato no site Público em 13 de janeiro de 2015. Disponível. In: Público - www.publico.pt. Consultado em 08/01/2017. Tradução de Marquessuel Dantas de Souza. E-mail: marquessuelgf@ hotmail.com.
} 
Nota do tradutor: É interessante observarmos que após a nomeação de Jean-Paul Sartre como o vencedor do Prêmio Nobel, em 22 de outubro de 1964, o mesmo declarou à imprensa sueca (declaração esta traduzida para o francês no jornal Le Figaro $^{2}$ ) que sempre havia recusado distinções oficiais. Eis, em nossa consideração, uma das razões para nunca ter ensinado, por exemplo, como professor universitário, no Collège de France. Não obstante acrescentou: “um escritor que assume posições políticas, sociais ou literárias deve agir com os meios que lhes são próprios, isto é, com a palavra escrita" [...] "Nenhum escritor deve deixar-se transformar em Instituição". Ou mais precisamente: "o escrito deve, portanto, recusar por deixar-se transformar em instituição" [L'écrivain doit donc refuser de se laisser transformer en institution]. Porém, isto não representa nenhuma crítica aqueles já premiados, nos diz.

Manifestamente Sartre na mesma declaração ainda pontua: [je ne veux pas être institutionnalisé] - “não quero ser institucionalizado”. É interessante esta postura de um intelectual do grau de Jean-Paul Sartre. No mais, sua atitude marcou época, sendo, por assim dizer, uma ação polêmica e aparentemente escandalosa, por sua vez engendrou admiração.

\footnotetext{
2 Para o desenvolvimento dos nossos argumentos consultamos a matéria (de 1964) publicada no Le Figaro de 22 de outubro de 2014, quando do cinqüentenário da publicação original da declaração de Sartre. Prix Nobel de lettérature: les raisons du refus de Sartre. Disponível. In: Le Figaro www.lefigaro.fr. Par Camille Lestienne. Consultado em 08/01/2017. Nota do tradutor.
}

\begin{tabular}{|l|l|l|l|l|}
\hline Gonista Q Alatectus & Ano 4 & n. 10 & Janeiro - Julho 2017 & p. 270-271 \\
\hline
\end{tabular}

